\title{
Nonlinear Finite Element Analysis for Mooring Chain Considering OPB/IPB
}

\author{
Min-suk Kim* and Yooil Kim ${ }^{*}$ \\ "Department of Naval Architecture and Ocean Engineering, Inha University, Incheon, Korea \\ $\mathrm{OPB} / \mathrm{IPB}$ 를 고려한 계류체인의 비선형 수치해석 \\ 김민석* 김유일* \\ *인하대학교 조선해양공학과
}

KEY WORDS: Out-of-plane bending 면외굽힘, In-plane bending 면내굽힘, Interlink stiffness 링크간 강성, Stress concentration factor 응력집중계수, Critical elastic slip 임계탄성미끌림

\begin{abstract}
The design of the mooring line to maintain the position of an offshore structure in rough marine environments is recognized as a very important consideration. Conventional fatigue evaluation of a mooring line was performed by considering the tensile force acting on the mooring line, but the mooring line broke after 238 days in the girassol area even though the expected fatigue life was expected to be longer. The causes of this event are known to be due to OPB/IPB (out-of-plane bending/in-plane bending) caused by chain link friction due to the excessive tensile strength of the mooring line. In this study, three models with different boundary conditions were proposed for fatigue analysis of a mooring line considering OPB/IPB. Interlink stiffness was calculated by nonlinear structure analysis and a stress concentration factor was derived. In addition, the sensitivity of interlink stiffness according to the magnitude of tensile force, large deformation effect, and coefficient of friction was analyzed, and the effect of critical elastic slip and bending moment calculation position on interlink stiffness was confirmed.
\end{abstract}

\section{1. 서 론}

해양구조물이 특정 위치에 설치되면 약 20 년의 운용기간동안 해당 위치에서 자리를 유지할 필요가 있으며 이에 따라 거친 환경 하중 하에서 위치를 유지하기 위한 계류라인의 설계는 매 우 중요한 요소 중 하나이다. 부유식 해양구조물의 계류 방법은 현수선 방식(Catenary type)과 인장각식(Taut type)으로 분류할 수 있고 일반적으로 계류라인을 구성하는 체인링크의 피로평가 는 체인링크에 작용하는 인장력의 변화를 통해 수행되어 왔다. 그러나 서아프리카의 Girassol 지역에 설치된 원유하역 부유 구 조물(Offloading buoy)이 운용 235일 만에 파손되는 사건이 발생 하였으며, 이에 대한 많은 분석이 진행된 결과 계류라인의 과도 한 인장력의 증가로 인한 체인링크 간 마찰에 의해 유발되는 면 내외 굽힘(OPB/IPB, Out-of-plane/In-plane bending)이 그 주요 원인으로 지목되었다. 이후 계류라인의 피로 강도 평가 시 면 내외 굽힘의 효과를 고려하기 위한 많은 노력들이 이어져왔다 (Rampi et al., 2016a; Rampi et al., 2016b; Hwang, 2012; Bureau Veritas, 2014; Choung and Han, 2016). Melis et al.(2005)은 면외
굽힘 거동의 역학적 특성을 설명하고 통해 다양한 체인지름과 체인등급의 면외굽힘 응력을 측정하였으며, 면외굽힘 응력과 선인장력(Pretension) 및 링크 간 각도(Interlink angle)의 관계를 밝히고 있다. Vargas and Jean(2005)은 면외 응력과 링크 간 각 도를 구하기 위한 수치해석방법을 제시하고 있으며 Melis et al. (2005)의 실험결과와 비교검증을 수행하였다. Lim et al.(2010)은 수치해석 모델을 통해 마찰계수, 검사하중, 공칭 인장력, 체인지 름의 면외 굽힘 모멘트의 영향을 주는 인자를 확인하였다. Rampi et al.(2016a)와, Rampi et al.(2016b)은 실스케일의 체인 모 델에 대한 다축피로실험을 수행하여 면 내외 굽힘 변형에 의한 체인의 피로강도를 평가하였으며, 실험 모델에 대한 상세한 유 한요소해석을 수행하였다.

본 연구에서는 경계조건이 서로 다른 3 가지 모델을 제시하고 비선형 구조해석을 통해 링크 간 강성(Interlink stiffness) 및 응 력집중계수(Stress concentration factor)를 계산하였다. 또한 대변 형 효과유무, 인장력, 마찰계수의 크기에 따른 링크 간 강성의 민감도를 분석하고 마찰모델과 굽힘모멘트 계산위치에 따른 링 크 간 강성의 영향을 확인하였다.

Received 16 January 2017, revised 23 January 2017, accepted 22 June 2017

Corresponding author Yooil Kim: +82-32-860-7347, yooilkim@inha.ac.kr

(C) 2017, The Korean Society of Ocean Engineers

This is an open access article distributed under the terms of the creative commons attribution non-commercial license (http://creativecommons.org/licenses/by-nc/3.0) which permits unrestricted non-commercial use, distribution, and reproduction in any medium, provided the original work is properly cited. 


\section{2. 이론적 배경}

\section{1 링크 간 거동}

인접한 링크 간의 거동은 그 특성에 따라 락킹, 롤링 및 슬라이 딩 모드로 구분되며 각각의 링크 간 거동의 특성은 다음과 같다.

\section{(1) 락킹 모드(Locking mode)}

제조단계에서 발생하는 체인표면의 변형과 계류라인의 인장 력의 증가로 인해 체인링크 접촉면에서 마찰력이 증가하는 현 상이 발생한다. 이러한 이유로 체인링크가 자유롭게 회전하거 나 미끄러지지 않고 상호 고정되어 있는 상태가 발생하게 되는 데 이를 락킹 모드라고 일컫는다. 락킹 모드는 체인링크 접촉면 에서의 마찰력이 최대정지 마찰력을 초과하기 전까지 발생되며 면 내외 굽힘응력의 주요 원인이 된다.

\section{(2) 롤링 모드(Rolling mode)}

롤링 모드는 낮은 인장력에서 체인링크가 자유롭게 회전 가능 한 상태를 의미한다. 롤링 모드에서의 체인 간 상대거동은 하나의 체인이 다른 체인의 표면 따라 구름으로 발생하는 것으로 접촉면 혹은 선의 지속적인 이동을 동반한다. 롤링모드에서도 면 내외 굽 힘응력이 발생되나 락킹 모드에서 유발되는 응력에 비해서 무시 할 수 있을 만큼 작은 값을 가지는 것으로 알려져 있다.

\section{(3) 슬라이딩 모드(Sliding mode)}

슬라이딩 모드는 체인링크가 다른 체인링크의 표면을 따라 미끄러지는 상태를 의미한다. 주로 체인 간 마찰력이 최대 정지 마찰력을 넘은 상태에서 발생되며 슬라이딩 모드에서 유발되는 응력은 운동마찰력에 의해 유발되는 값으로 미끌림이 발생하는 동안 일정한 값을 가진다.

\section{2 면 내외 굽힘모멘트 계산}

인접한 체인링크의 중립축 사이의 각도를 링크간 각도로 정의하 고 있으며, 링크 간 강성은 링크 간 각도에 따른 인접한 체인링크의 접촉면에 발생하는 면 내외 굽힘모멘트의 변화량으로 정의된다. 링 크 간 강성을 구하기 위해서는 면 내외 굽힘모멘트의 계산이 선행되 어야 하며 이를 위해 다음과 같은 방법으로 계산을 수행한다.

면 내외 굽힘모멘트는 체인링크 간 접촉면에서 계산이 수행 되며 면외 및 면내 굽힘 모델에 따라 이를 도시화 하면 아래의 Figs. 1-2와 같이 나타낼 수 있다. 면내 및 면외 굽힘 모멘트는 첫 번째 및 두 번째 체인이 접촉하는 위치에서 발생하는 내력 으로써 면 내외 굽힘 모델에 대한 모멘트 평형을 고려하여 식 (1) 및 (2)와 같이 구할 수 있다(Hwang, 2012).

$$
\begin{aligned}
& M_{O P B}=M_{\text {Rotation }}+N T\left(D_{x} \sin \theta-D_{y} \cos \theta\right) \\
& M_{I P B}=M_{\text {Rotation }}+N T\left(D_{x} \sin \theta-D_{z} \cos \theta\right)
\end{aligned}
$$

식 (1) 및 (2)에서 $M_{O P B}, M_{I P B}$ 는 접촉면에서 발생하는 면 내외 굽힘 모멘트를 나타내며 $M_{\text {Rotation }}$ 는 하중점에서 부가된 모멘트를 표현한다. $N T$ 는 공칭인장력을 의미하며 $D_{x}, D_{y}$ 는 접촉면과 하중점 까지의 거리를, $\theta$ 는 링크회전각도(Prescribed angle)을 나타낸다.

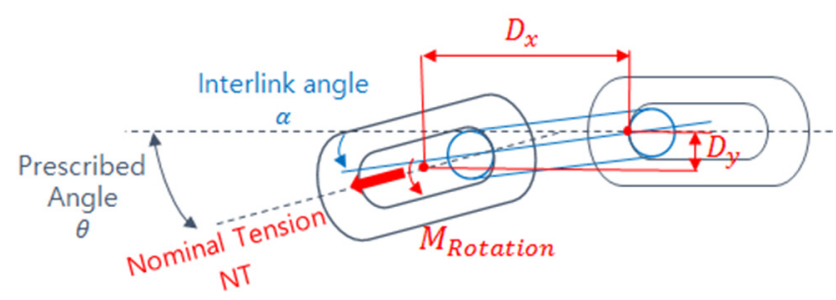

Fig. 1 Illustration of OPB mode

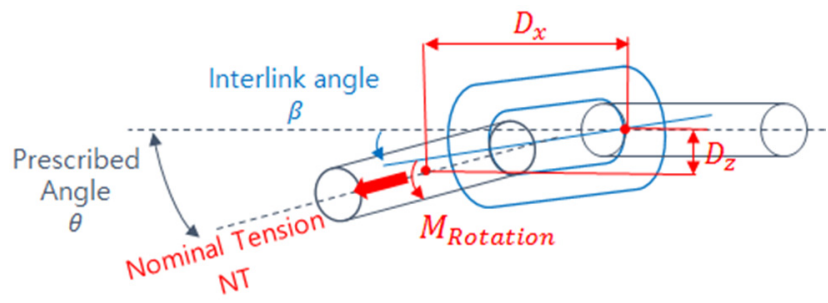

Fig. 2 Illustration of IPB mode

\section{3 쿨롱 마찰모델(Coulomb friction model)}

비선형 유한요소해석을 통해 링크 간 강성 및 체인표면의 응 력집중계수 등을 산출하기 위해서는 체인 간 마찰현상을 정확 하게 모사할 필요가 있다. 본 해석에서는 쿨롱 마찰모델을 적용 하여 링크간 마찰 거동을 모사하였다. 쿨롱 마찰모델은 크게 건 모델(Dry model), 점성 모델(Viscous model), 탄성 모델(Elastic model)로 구분이 가능하다. Fig. 3은 건 모델과 탄성모델에 있어 마찰력과 접촉면의 상대속도 혹은 상대변위의 관계를 도시한 그림이다. 건 모델의 경우 상대속도(혹은 변위)가 0 인 경우 접 촉하는 물체에 작용하는 외력의 크기에 해당되는 마찰력이, 상 대속도(혹은 변위)가 발생하는 경우 마찰계수와 법선력의 곱에 해당되는 마찰력이 발생하게 된다. 건 모델은 마찰력의 불연속 적인 변화로 인해 수치적 불안전성을 내포하고 있는데 이러한 문제를 해결하기 위해 탄성모델이 도입되었다. 탄성 모델의 경 우 접촉하는 물체가 접착상태에 있더라도 미소한 양의 상대변 위가 발생하는 것으로 간주하고 미끌림 량에 비례하는 마찰력 의 발생을 가정한다. 이때 두 면간에 발생하는 미끌림에 대한 강성은 마찰력이 임계값에 도달하는 순간의 탄성 미끌림 량인 임계 탄성미끌림량 $\left(l_{0}\right)$ 과 밀접한 관련을 가지게 된다.

본 해석에서는 건모델이 가지는 수치적 불안정성을 피하기 위해 탄성 쿨롱모델을 적용하여 해석을 수행하였으며, 접촉하는 두 물체 의 표면에 작용하는 마찰력은 식 (3)과 같이 정의하였다.

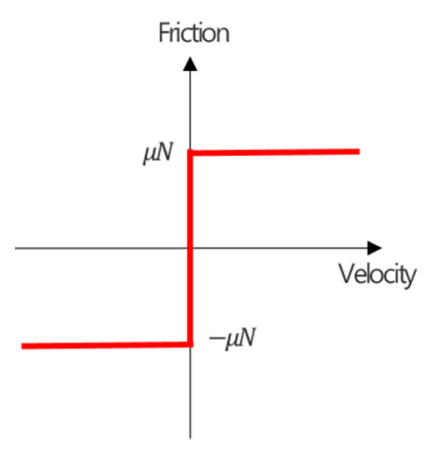

$<$ Dry model >

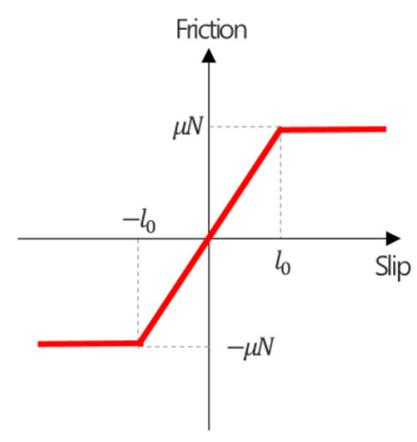

$<$ Elastic model >
Fig. 3 Dry, elastic Coulomb model 


$$
F_{t}=\frac{\mu N}{l_{0}} s
$$

여기서 $\mu$ 는 마찰계수, $N$ 은 법선력, $s$ 는 미끌림량을 나타낸다.

\section{4 응력집중계수}

체인 표면 임의의 위치에서 응력집중계수(SCF, Stress concentration factor)를 구하기 위해 링크의 기하학적 형상 의해 야기된 국부 응력을 비선형 구조해석을 통해 도출했다. 또한 국부응력은 응 력을 유발하는 성분에 따라 인장력에 기인한 인장응력(Tension stress, $\left.\sigma_{t t}\right)$, 면외 굽힘모멘트에 기인한 면외 굽힘응력(OPB stress, $\left.\sigma_{O P B}\right)$ 그리고 면내 굽힘모멘트에 기인한 면내 굽힘응력 (IPB stress, $\sigma_{I P B}$ )으로 구분하였다.

응력집중계수는 체인링크간의 접촉부를 제외한 체인 응력 집 중부의 최대 주응력(Max principal stress)과 체인 중앙에서 공칭 단면에 대한 공칭 인장응력의 비로써 도출하였다. Fig. 4와 같이 체인링크 표면에서 특정 절점에서의 응력집중계수는 식 (4), (5), (6)과 같이 표현된다(Hwang, 2012).

$$
\begin{aligned}
& S C F_{T T i}=\frac{\sigma_{t t i}}{\sigma_{n}} \\
& S C F_{O P B i}=\frac{\sigma_{O P B i}}{\sigma_{n}} \\
& S C F_{I P B i}=\frac{\sigma_{I P B i}}{\sigma_{n}}
\end{aligned}
$$

여기서 $S C F_{T T i}$ 는 절점 $i$ 에서의 인장 응력집중계수를, $S C F_{O P B i}$ 및 $S C F_{I P B i}$ 는 각각 절점 $i$ 에서의 면외 및 면내 굽힘 응력집중계수를 나타낸다. $\sigma_{n}$ 은 체인 중앙 단면에서의 공칭응력을 의미한다.

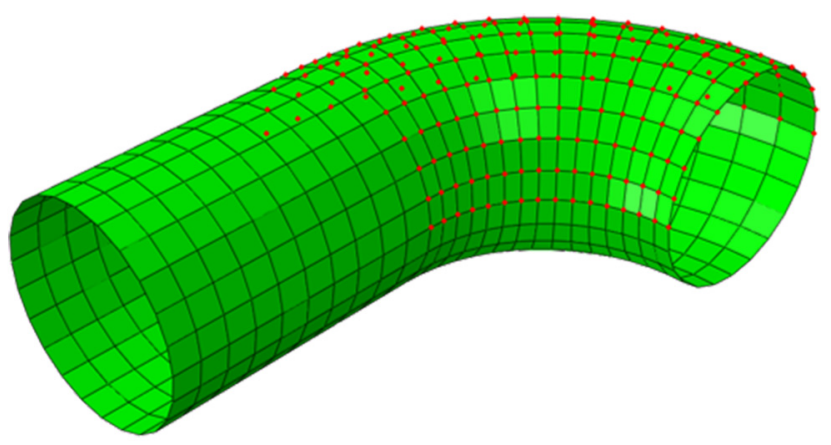

Fig. 4 Nodes on the chain surface

\section{3. 비선형 구조해석}

\section{1 해석모델 및 하중단계}

본 연구에서는 체인의 인장력에 의해 유발되는 인접 체인간 의 링크 간 강성 및 면 내외 굽힘에 의한 응력집중계수를 비선 형 유한요소해석을 통해 얻고자 하였다. 유한요소해석은 상용 해석 프로그램인 ABAQUS Ver.6.14를 이용하였다. 본 연구에서
고려된 체인은 R3 등급의 지름 $147 \mathrm{~mm}$ 체인링크로 Fig. 5 와 같 은 형상과 치수를 가진다.

유한요소모델에서는 굽힘에 의한 체적구속(Volume locking)을 방지하기 위해 8절점 비적합요소(C3D8I)를 사용하였고 체인링 크 표면에서의 응력을 구하기 위해 강성이 없는 4절점 막요소 (M3D4)를 사용하였다. 요소의 크기는 약 $10 \mathrm{~mm}$ 로 결정하였으며 이는 체인의 곡률에 따른 형상을 정확하게 모사함과 동시에 해 석의 결과를 통해 얻어진 응력의 수렴성을 보증하는 값이다 (Rampi, 2016a; Rampi, 2016b).

체인링크의 제조 단계에서 검사하중(Proof loading)으로 인한 소성변형을 구현하기 위해 Ramberg and Osgood(1943)가 제시한 응력-변형율 관계식 (7)을 적용하였다.

$$
\varepsilon_{n}=\frac{\sigma_{n}}{E}+\alpha \frac{\sigma_{y}}{E}\left(\frac{\sigma_{n}}{\sigma_{y}}\right)^{n}
$$

여기서, $\sigma_{n}, \varepsilon_{n}, \sigma_{y}$ 는 각각 공칭응력, 공칭변형율 및 항복응력을 나타내며, $\alpha, E, n$ 는 각각 오프셋, 탄성계수 및 경화지수를 나 타낸다. Table 1은 해석에 적용된 재료 상수를 요약한 것이다 (Hwang, 2012).

Fig. 6은 유한요소 모델에서 적용한 하중의 단계를 표현한 그림이 다. 파란색으로 표시한 것은 체인링크에 작용하는 축 방향 인장력의 크기를 나타내며, 빨간색으로 표시한 것은 $\mathrm{OPB} / \mathrm{IPB}$ 를 유발시키기 위한 링크회전각도를 의미한다. 계류라인을 구성하는 체인링크는 제작단계에서 여러 가지 검사를 수행한다. 이중 검사하중 시험 (Proof loading test)단계는 최소파단하중(MBL, Minimum breaking load)의 통상 $70 \%$ 에 해당하는 인장력을 가하고 제거하는 시험이다. 높은 검사하중으로 인하여 체인링크의 접촉면에 소성변형이 발생하 여 기하학적 형상의 변화가 야기되며 이를 해석에 반영하기 위해 최소파단하중의 $70 \%$ 인 $10875 \mathrm{kN}$ 을 가하고 다시 이를 제거하는 단계를 도입하였다. 운용단계에서 작용하는 인장력을 구현하기 위한 인장단계 와 링크 간 각도를 유발시키기 위한 면 내외 회전단계를 고려하였다.

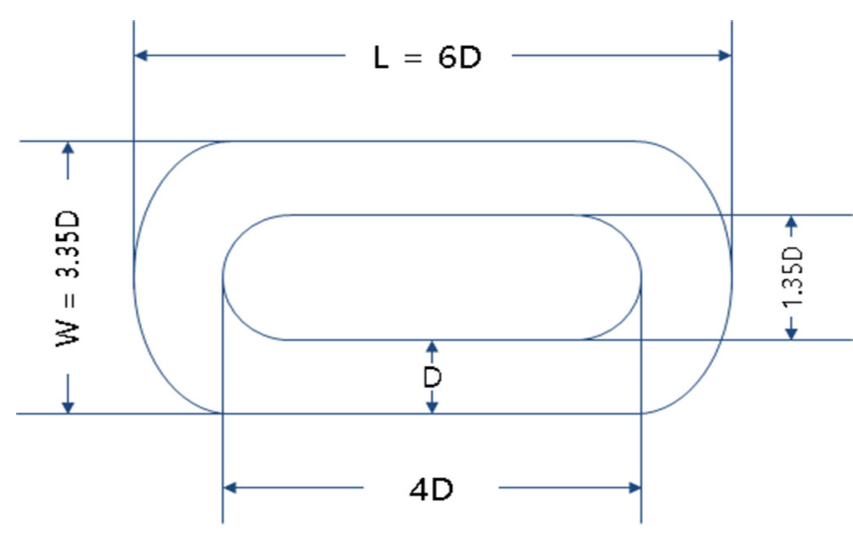

Fig. 5 Geometry of R3 studless chain

Table 1 Material properties

\begin{tabular}{ccccc}
\hline \hline Parameters & $\begin{array}{c}\text { Yield stress } \\
{[\mathrm{MPa}]}\end{array}$ & Offset & $\begin{array}{c}\text { Young's modulus } \\
{[\mathrm{MPa}]}\end{array}$ & $\begin{array}{c}\text { Hardening } \\
\text { exponent }\end{array}$ \\
\hline Value & 520 & 0.804 & 20900 & 15.84 \\
\hline
\end{tabular}




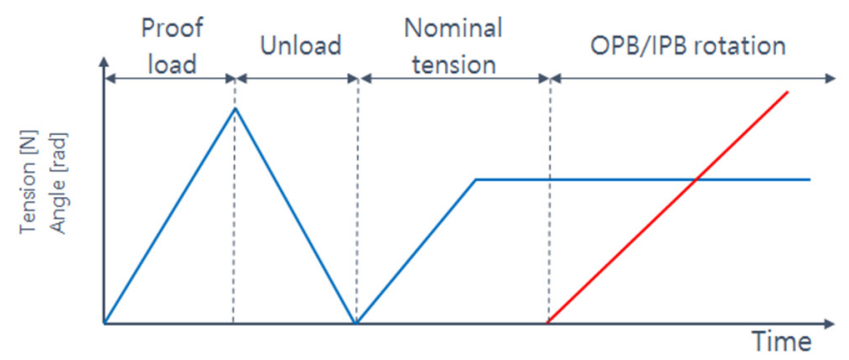

Fig. 6 Time steps of loading

\section{2 모델링과 경계조건}

(1) 1 링크 모델

체인링크에 작용하는 면 내외 굽힘모멘트를 구현하기 위해 아래의 Fig. 7 및 Fig. 8과 같이 면외 및 면내 굽힘모델에 대한 형상을 모델링 하였다. 모든 체인에 대칭조건을 부여하여 완전 한 체인링크의 형상을 이상화 하였으며 오른쪽 체인의 절단면 에 고정조건을 부여하여 수직방향 변위를 제어하였다. 왼쪽체 인 절단면 상에 위치하는 절점을 붉은점으로 표시된 하중점에 기구학적 연성(Kinematic coupling)조건으로 구속하여 인장력과 링크 회전각도를 고려하여 중간체인의 면 내외 굽힘모멘트를 유발시켰다. 기구학적 연성은 기준점의 $y$ 및 $z$ 방향의 병진 변 위와 $x$ 방향의 회전 변위가 종속 절점과 연성되도록 하였다.

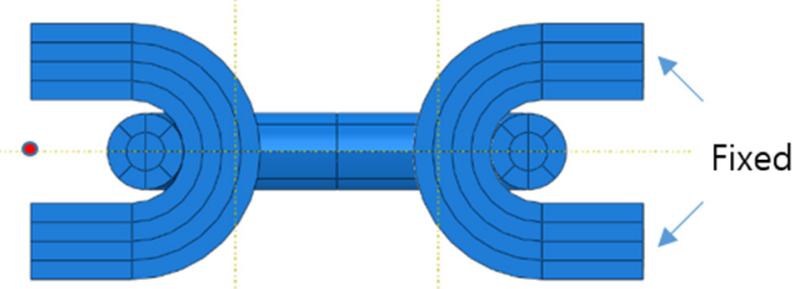
$\stackrel{4}{1}$

Fig. 71 link OPB model

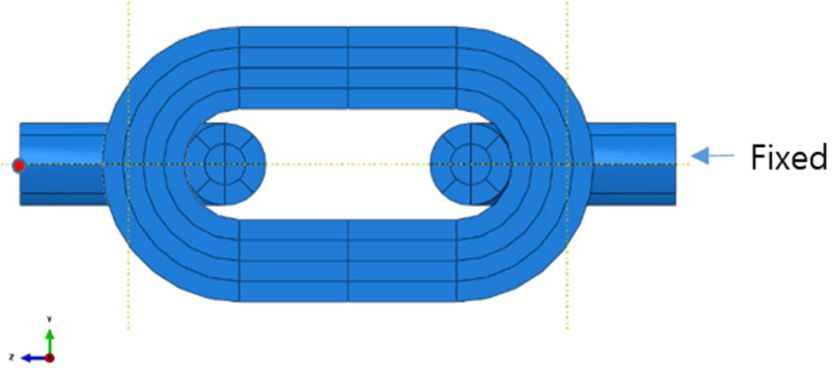

Fig. 81 link IPB model

(2) 수정된 1 링크 모델

Fig. 9와 10은 수정된 1 링크 모델로써 1 링크 모델과 기하학 적 형상은 동일하지만 오른쪽 체인의 상하부에 각각 강체면을 두어 체인의 수직방향 변위를 제어한 점에서 차이를 가진다. 이 는 실제 해양구조물에 계류라인 상부에 존재하는 stopper의 형 상을 모사하여 실제상황을 더 이상화하려 노력했다. 오른쪽 링 크의 절단면에는 대칭 경계조건을 부가하여 변위를 제어하였다.

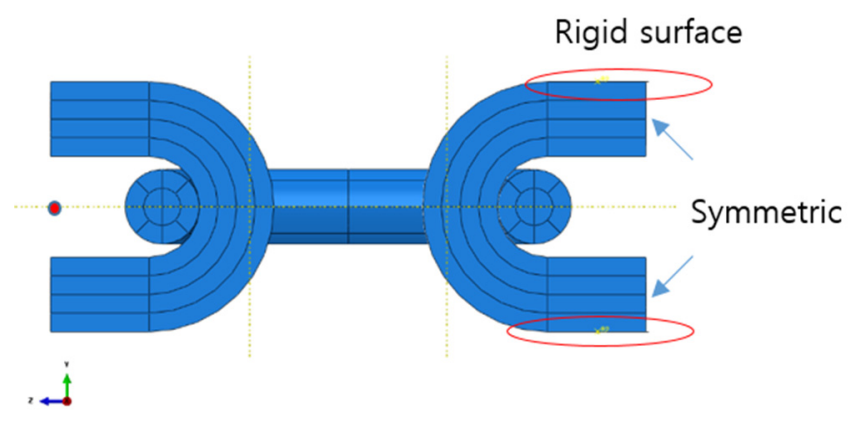

Fig. 9 Modified 1 link OPB model

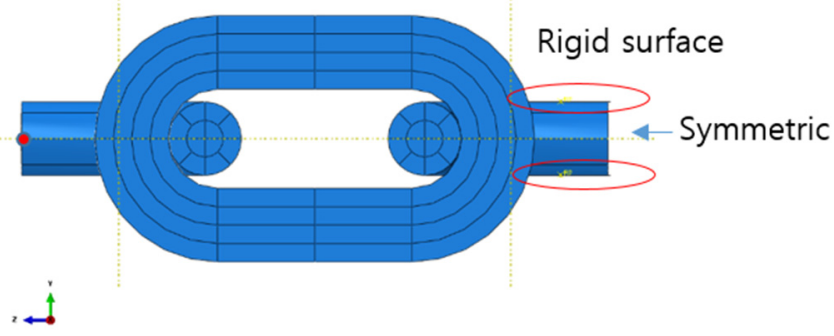

Fig. 10 Modified 1 link IPB model

(3) 2 링크 모델

2 링크 모델은 모델 양단에 부가되는 경계조건으로 인한 효 과를 최소화하기 위한 모델로써 Fig. 11과 12에 보인 바와 같은 형상을 가진다. 가장 오른쪽 체인의 절단면을 완전 구속하여 수 직방향 변위를 제어하였으며 가장 왼쪽체인의 면을 하중점에 연성시켜 구속한 후 하중을 부가하였다. 링크 간 강성을 위한 면 내외 굽힘모멘트 및 링크 간 각도는 경계조건을 부가한 양 끝단으로부터 가장 멀리 위치한 가운데 체인에서 계산하여 경 계조건으로 인한 영향을 최소화하고자 하였다.
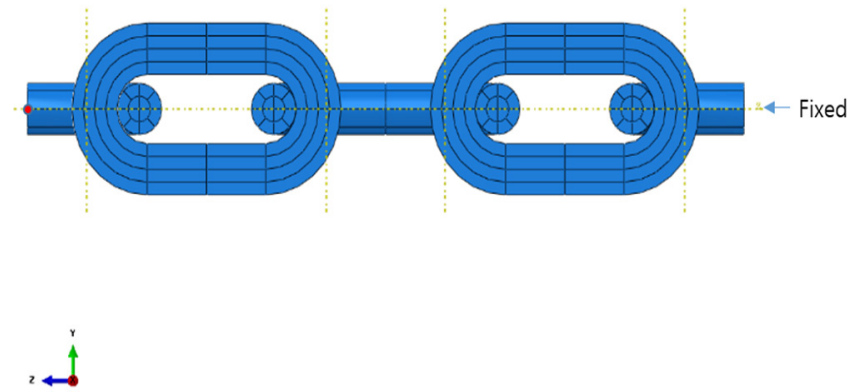

Fig. 112 link OPB model
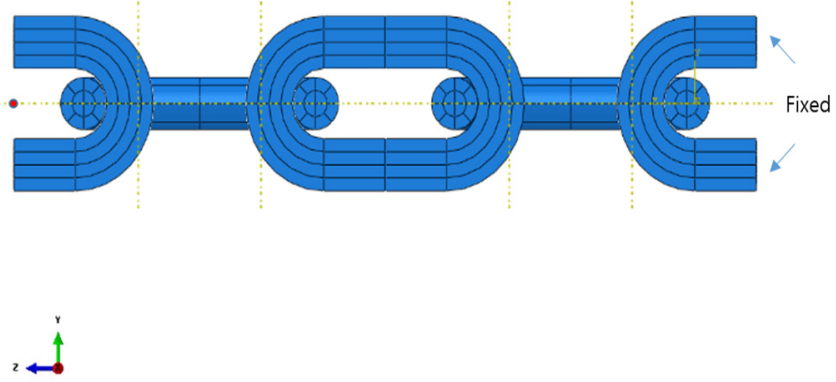

Fig. 122 link IPB model 


\section{4. 해석 결과}

링크간 강성은 구조해석을 통해 얻어진 면 내외 굽힘모멘트 와 링크 간 각도의 관계를 도시함으로써 얻을 수 있다. 링크 간 강성은 비선형 구조해석의 정도와 밀접한 관련을 가지는데 본 연구에서는 대변형 효과, 인장력 효과, 마찰모델 효과, 강성계산 위치에 따른 링크 간 강성의 민감도를 분석하였다. 또한, 링크 간 강성을 위해 수행된 해석 결과로 부터 도출된 체인 표면에 서의 응력집중계수를 계산하였다.

\section{1 대변형 효과}

링크 간 강성에 미치는 대변형의 영향을 확인하기 위해 3.2절 에서 제시한 3 가지 면외 굽힘 모델을 이용하여 대변형 효과의 유무에 따른 링크 간 강성의 민감도를 분석하였다. 모든 모델에 대해 0.7 의 마찰계수를, $1850 \mathrm{kN}$ 의 인장력을 부가하여 해석을 수 행하였다. Fig. 13은 각 모델 별 대변형 효과의 적용 여부에 따 라 링크 간 각도에 따른 $\mathrm{OPB}$ 모멘트를 표현한 그래프이다. Table 2는 모델에 따른 링크 간 강성을 수치적으로 보여주고 있 으며 대변형을 고려한 경우 "Large"로 대변형을 고려하지 않은 경우에는 "Small"로 표시하였다. 2 링크 대변형 모델과 수정된 1 링크 대변형 모델이 비교적 비슷한 링크 간 강성을 보여주고

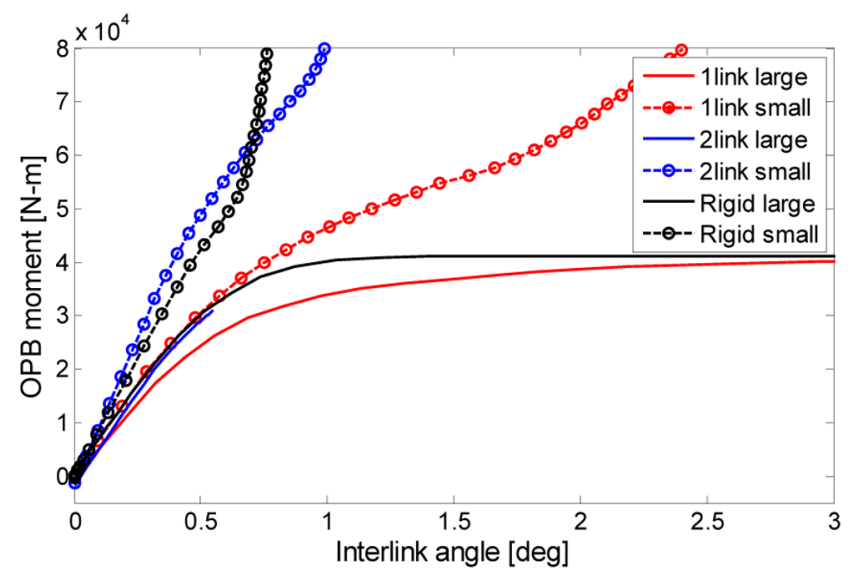

Fig. 13 Interlink angle VS OPB moment

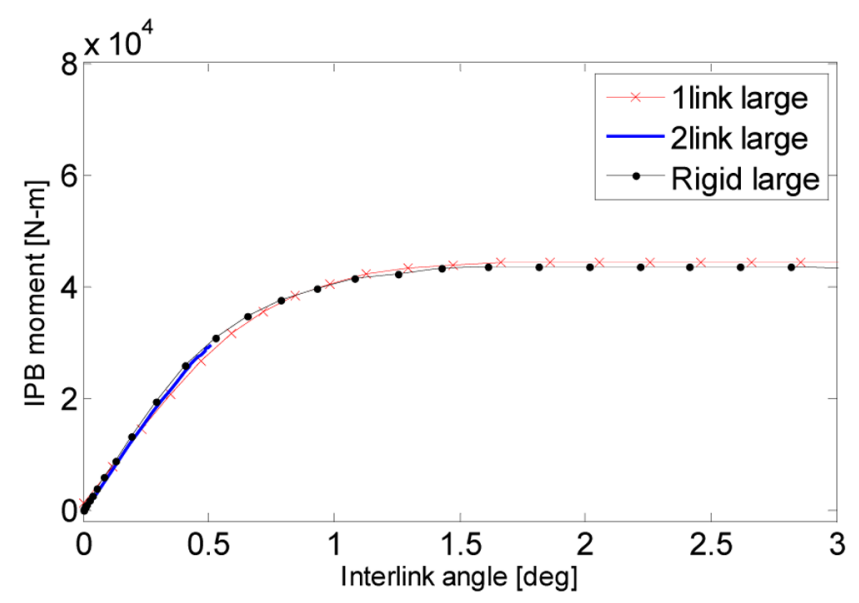

Fig. 14 Interlink angle VS IPB moment
Table 2 Interlink stiffness for different OPB models

\begin{tabular}{ccccccc}
\hline \hline Models & $\begin{array}{c}\text { 1link } \\
\text { large }\end{array}$ & $\begin{array}{c}\text { 1link } \\
\text { small }\end{array}$ & $\begin{array}{c}\text { 2link } \\
\text { large }\end{array}$ & $\begin{array}{c}\text { 2link } \\
\text { small }\end{array}$ & $\begin{array}{c}\text { Modified } \\
\text { large }\end{array}$ & $\begin{array}{c}\text { Modified } \\
\text { small }\end{array}$ \\
\hline $\begin{array}{c}\text { Stiffness } \\
{[\mathrm{kN}-\mathrm{m} / \mathrm{deg}]}\end{array}$ & 49.29 & 67.31 & 68.68 & 107.4 & 66.5 & 89.34 \\
\hline
\end{tabular}

Table 3 Interlink stiffness for different IPB models

\begin{tabular}{cccc}
\hline \hline Models & 1 link large & 2 link large & Modified large \\
\hline $\begin{array}{c}\text { Stiffness } \\
{[\mathrm{kN}-\mathrm{m} / \mathrm{deg}]}\end{array}$ & 56.04 & 64.18 & 67.34 \\
\hline
\end{tabular}

있음을 확인할 수 있으며 모든 모델에 있어 미소변형을 적용한 경우 슬라이딩모드 구간에서 비정상적인 거동을 보임을 확인할 수 있었다.

Fig. 14 및 Table 3은 면내굽힘 모델에 대하여 대변형을 적용하였 을 때의 링크 간 각도에 따른 IPB모멘트를 보여주고 있다. 면내 굽힘의 경우 면외 굽힘 모델과 달리 모델 간의 해석 결과 차이가 크게 나타나지 않는 경향을 보이는데 이는 면내 굽힘 모델에 있어 체인이 가지는 높은 굽힘 강성의 효과인 것으로 판단된다.

\section{2 인장력의 크기에 따른 영향}

인장력의 크기에 따른 링크 간 강성의 영향을 분석하기 위해 인장력을 변화시켜가며 해석을 수행하였다. 3.2절에서 제시한 1 링크 모델을 대상으로 마찰계수 0.7 을 적용하고 인장력을 최소 파단하중(MBL, Minimum breaking loading)의 $11.90 \%, 12.55 \%$, $13.19 \%, 13.88 \%, 14.48 \%$ 에 해당하는 인장력을 부가한 후 해석을 수행하였다. 각각의 경우 적용된 인장력은 $1850 \mathrm{kN}, 1950 \mathrm{kN}$, $2050 \mathrm{kN}, 2150 \mathrm{kN}, 2250 \mathrm{kN}$ 이며 Fig. 15 에 보인 바와 같이 인장력 의 크기가 커질수록 링크 간 강성이 커지는 경향이 나타남을 확인하였다. Table 4 는 인장력에 따른 링크 간 강성을 수치적으 로 정리한 것으로 인장력의 크기에 따른 링크 간 강성의 변화 는 상대적으로 작은 범위에서 변화함을 확인할 수 있다.

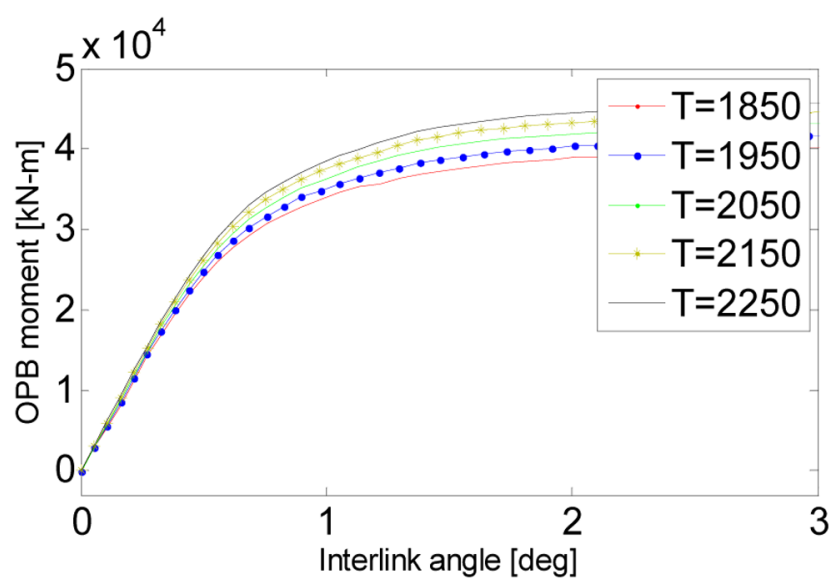

Fig. 15 Effect of tension on interlink stiffness

Table 4 Influence of tension on interlink stiffness

\begin{tabular}{cccccc}
\hline \hline Tension $[\mathrm{kN}]$ & 1850 & 1950 & 2050 & 2150 & 2250 \\
\hline $\begin{array}{c}\text { Stiffness } \\
{[\mathrm{kN}-\mathrm{m} / \mathrm{deg}]}\end{array}$ & 49.29 & 50.58 & 51.93 & 53.12 & 54.28 \\
\hline
\end{tabular}




\section{3 마찰계수에 따른 영향}

마찰계수의 변화에 따른 링크 간 강성의 영향을 분석하기 위 해 마찰계수 값을 변화시켜 가며 해석을 수행하였다. 3.2절에서 제시한 1 링크면 외 굽힘모델을 모델로 선정하였으며, 주어진 인장력 $(1850 \mathrm{kN})$ 하에서 마찰계수를 $0.3,0.5,0.7$ 로 차례로 변화 시켜가며 링크 간 강성의 변화를 체크하였다. 마찰계수의 영향 만을 확인하기 위해 해석 모델은 1 링크면 외 굽힘모델에 대해 서만 수행하였다. Fig. 16에 보인 바와 같이 마찰계수가 커질수 록 링크 간 강성 또한 증가하는 경향을 보여주었다. Table 5에 보인 바와 같이 강성 변화의 절대적인 양은 크게 나타나지 않 음을 확인할 수 있고, 다만 마찰계수의 크기에 따라 슬라이딩 모드가 발생하는 시점과 슬라이딩 모드 시의 면외 굽힘모멘트 에 있어 큰 차이를 보임을 확인할 수 있다.

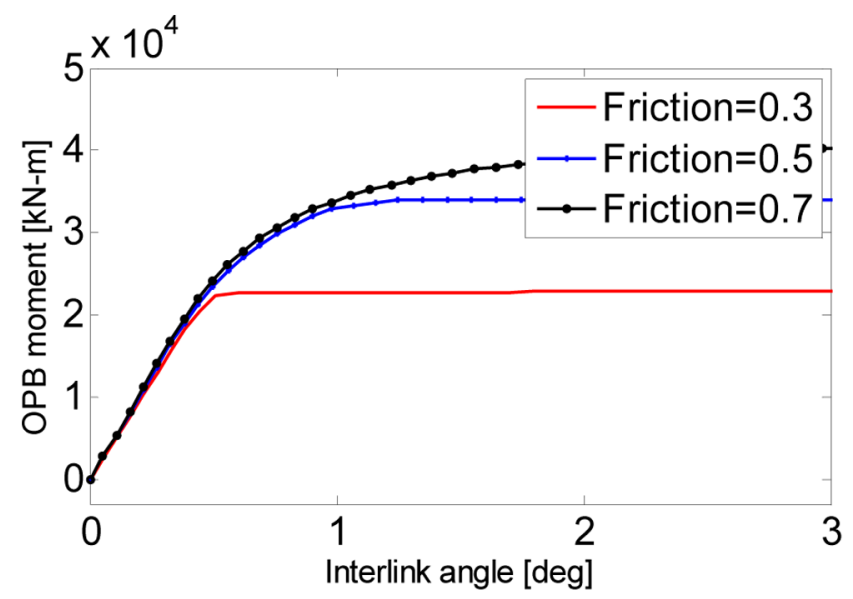

Fig. 16 Effect of friction coefficient on interlink stiffness

Table 5 Influence of friction coefficient on interlink stiffness

\begin{tabular}{cccc}
\hline \hline Friction coefficient & 0.3 & 0.5 & 0.7 \\
\hline $\begin{array}{c}\text { Stiffness } \\
{[\mathrm{kN}-\mathrm{m} / \mathrm{deg}]}\end{array}$ & 44.91 & 47.89 & 49.29 \\
\hline
\end{tabular}

\section{4 임계 탄성미끌림(Critical elastic slip)에 따른 영향}

임계 탄성미끌림량이 링크 간 강성에 미치는 영향을 분석하 기 위해 임계 탄성미끌림량을 변화시켜가며 해석을 수행하였다. 3.2절에서 제시한 2 링크 면내 굽힘모델을 모델로 선정하였으 며, 0.7의 마찰계수와(Hwang, 2012) $1850 \mathrm{kN}$ 의 인장력을 부가하 고 임계 탄성미끌림량의 크기를 $0.00005 \mathrm{~m}, 0.0001 \mathrm{~m}, 0.0002 \mathrm{~m}$, $0.0004 \mathrm{~m}$ 로 변화시켜가며 해석을 수행하였다. Fig. 17과 Table 6 에 보인 바와 같이 임계 탄성미끌림량이 작아질수록 링크 간 강성이 증가하는 경향을 확인할 수 있는데, 이는 주어진 마찰계 수 하에서 임계 탄성 미끌림량이 작을수록 마찰력-미끌림량의 기울기가 증가하기 때문이다. 임계 탄성미끌림량에 따른 링크 간 강성의 변화는 비교적 크게 나타났으며 이는 링크 간 강성 계산 시에 마찰 모델의 적용 및 임계 탄성미끌림량의 결정에 주의를 요할 필요가 있음을 의미한다. 임계 탄성미끌림량은 접 촉하는 체인의 표면 상태와 밀접하게 연관된 물리량으로 실험 적으로 결정되어야 할 값이다.

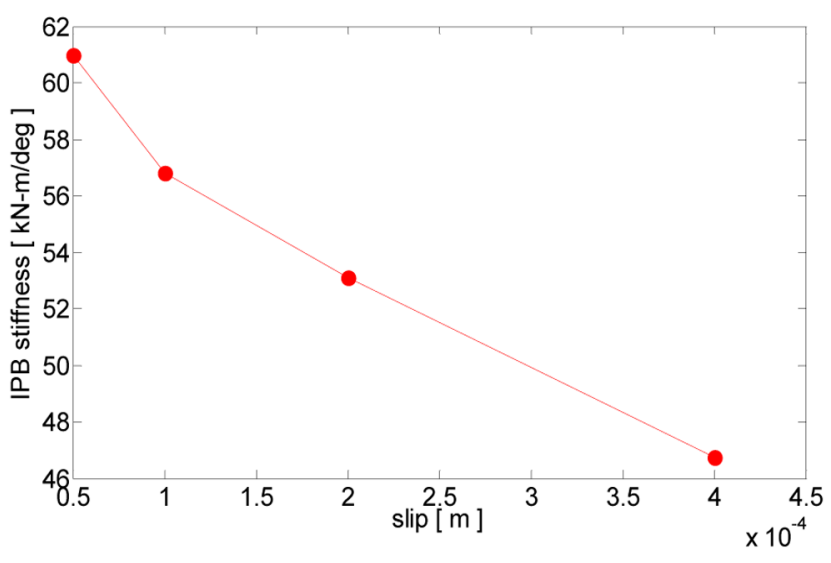

Fig. 17 Effect of elastic slip on interlink stiffness

Table 6 Influence of elastic slip on interlink stiffness

\begin{tabular}{ccccc}
\hline \hline Elastic slip [m] & 0.00005 & 0.0001 & 0.0002 & 0.0004 \\
\hline $\begin{array}{c}\text { Stiffness } \\
{[\mathrm{kN}-\mathrm{m} / \mathrm{deg}]}\end{array}$ & 60.98 & 56.80 & 53.12 & 46.74 \\
\hline
\end{tabular}

\section{5 모멘트 계산 위치에 따른 영향}

Fig. 18은 2 링크면 외 굽힘모델을 강체 보와 탄성 회전 스프 링으로 이상화한 모델을 나타낸다. 2 링크면 외 굽힘모델은 탄 성 회전 스프링으로 연결된 강체 보에 축방향 인장력과 강제 회전변위를 부가한 단순 모델로 치환이 가능하다. 탄성 회전 스 프링에 대한 가정은 링크 간 강성이 락킹 모드 시에 발생하는 링크 간 상대회전량에 따라 결정되기 때문이다.

2 링크면 외 굽힘모델에 포함된 4개의 링크 연결부는 동일한 링크 간 강성을 가질 것이므로 이에 따라 각각의 위치에서의 굽힘 모멘트와 링크 간 각도를 계산하고 링크 간 강성을 계산 하여 그 결과를 비교하였다. 해석에 적용된 인장력은 $1850 \mathrm{kN}$ 이 며 마찰계수는 0.7 로 가정하였다.
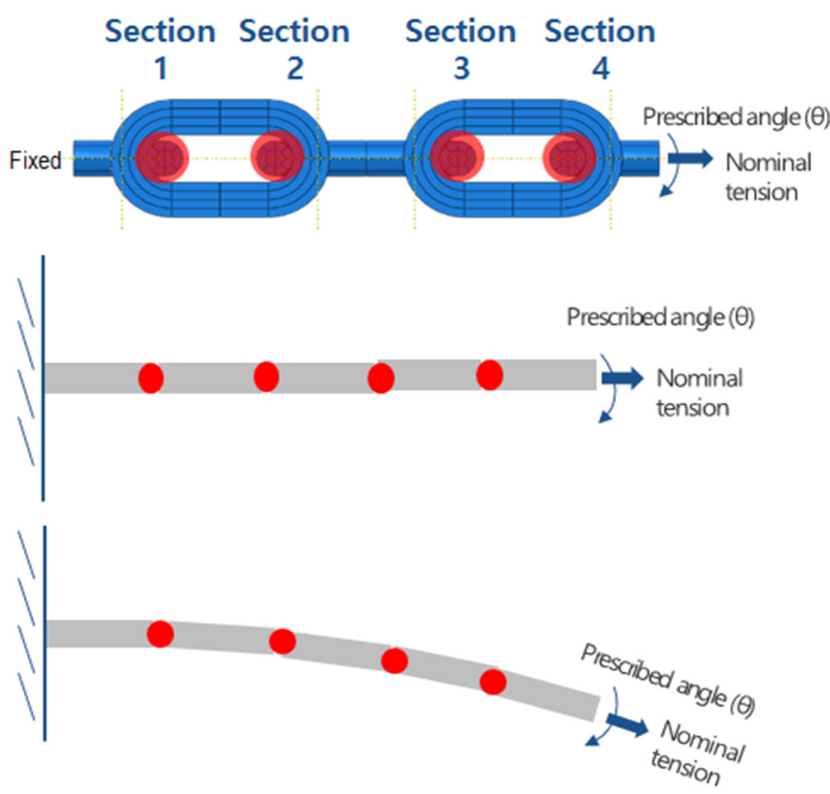

Fig. 18 Idealization of 2 link OPB model 
Fig. 19는 링크회전각이 $1.8^{\circ}$ 일때의 면외 굽힘모멘트와 링크 간 각도를 계산 위치별로 나타낸 그래프이다. 2 링크면 외 굽힘 모델이 끝단에 집중하중이 작용하는 외팔보로 근사되는 상황을 고려하면 지지점에서 멀어질수록 굽힘 모멘트 및 링크 간 각도 가 감소함을 기대할 수 있다. 이상적인 경우 굽힘 모멘트와 링크
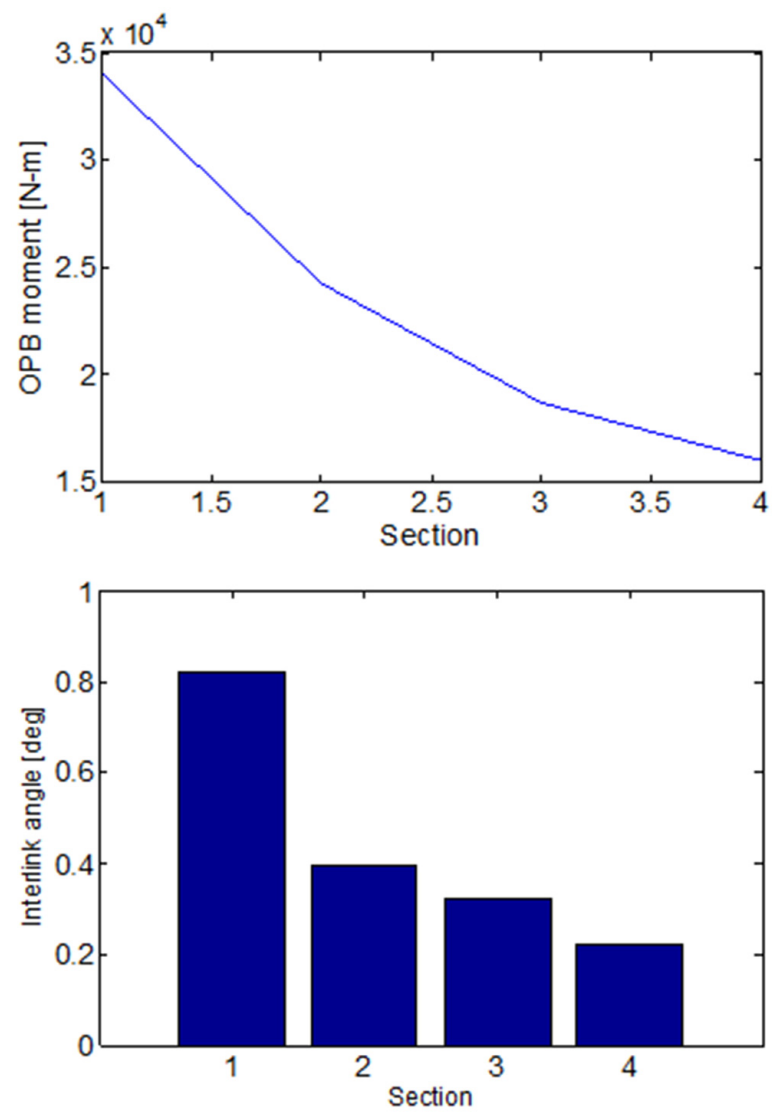

Fig. 19 OPB moment, interlink angle per section

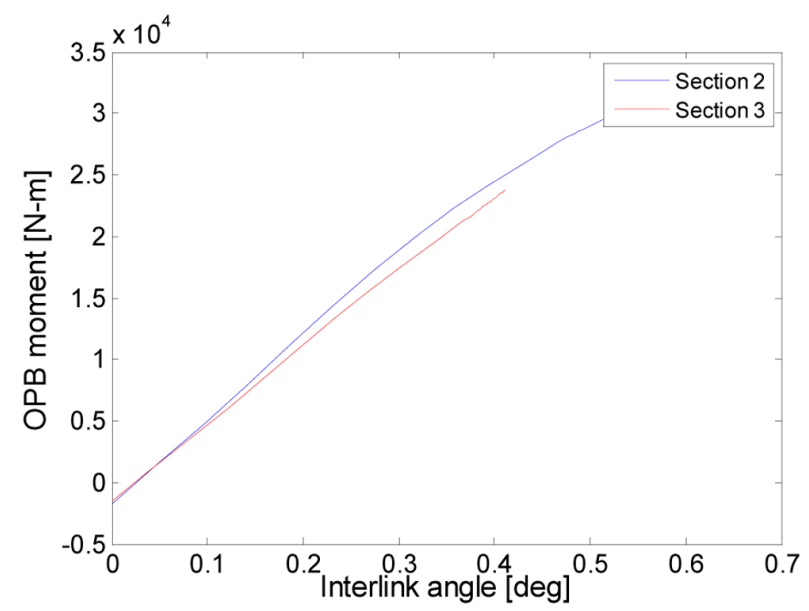

Fig. 20 Interlink angle VS OPB moment per section

Table 7 Interlink stiffness per sections

\begin{tabular}{ccc}
\hline \hline Models & Section 2 & Section 3 \\
\hline $\begin{array}{c}\text { Stiffness } \\
{[\mathrm{kN}-\mathrm{m} / \mathrm{deg}]}\end{array}$ & 68.68 & 62.54 \\
\hline
\end{tabular}

간 각도는 선형적으로 감소하여야 하며 그 비율은 일정한 값을 가지는 것이 타당하나 경계조건의 효과, 모멘트 계산식의 오차 등으로 인해 기대와 다른 결과를 얻게 되었다.

Fig. 20은 2, 3 번 연결부에서의 링크 간 각도와 면외 굽힘모멘 트 관계를 나타내는 것으로 1,4 번 연결부와 달리 비교적 유사 한 거동을 보임을 확인할 수 있다. Table 7에 정리된 바와 같이 링크 간 강성의 값도 큰 차이를 보이지 않음을 확인할 수 있었 다. 2 링크 이상의 다링크 모델을 적용하여 해석하는 경우 모델 의 중앙부에 근접한 링크 연결부를 선택하고 해당 링크 연결부 에 대한 굽힘 모멘트를 이용하여 링크 간 강성을 계산하는 것 이 바람직한 것으로 판단된다.

\section{6 응력집중계수}

본 연구에서는 체인 링크간의 접촉부를 제외한 체인 응력 집 중부의 최대 주응력(Max principal stress)과 체인 중앙부 공칭 단 면에 대한 공칭 인장응력의 비로써 정의되는 응력집중계수를 도출하였다. Fig. 21은 $1850 \mathrm{kN}$ 의 인장력 하에서 인장력에 의한 응력집중계수 및 면 내외 굽힘에 의한 응력집중계수를 굽힘모 드에 따라 보여주고 있다. 면 내외 굽힘이 발생하는 경우 링크 간 각도가 증가함에 따라 최대응력이 발생하는 위치가 조금씩 이동해 나감을 확인할 수 있다.

Table 8 과 9는 면외 및 면내 굽힘 모델의 특정 절점에 대한 응력집중계수의 변화를 링크 간 각도에 따라 요약한 것이다. 해 당 절점은 Fig. 22에 보인 바와 같이 면외 및 면내 모델에 대해 각각 $\mathrm{A}, \mathrm{B}$ 및 $\mathrm{A}^{\prime}, \mathrm{B}^{\prime}$ 의 위치로써, $\mathrm{A}$ 및 $\mathrm{A}^{\prime}$ 은 인장력만 작용한 경우 최대응력이 발생하는 위치이며 $\mathrm{B}$ 및 $\mathrm{B}^{\prime}$ 은 면외 및 면내 굽힘이 발생하는 경우 최대응력이 발생하는 위치이다. Table에 보인 바와 같이 링크 간 각도가 증가하는 경우 $\mathrm{B}$ 및 $\mathrm{B}^{\prime}$ 의 위치 에서의 응력집중계수가 증가하는 것을 확인할 수 있는데 이는 굽힘에 의해 최대응력의 발생지점이 지속적으로 이동하고 있음 을 의미하는 결과이다.

Table 8 OPB model SCF

\begin{tabular}{ccc}
\hline \hline Interlink angle $[\mathrm{deg}]$ & $\mathrm{A}$ & $\mathrm{B}$ \\
\hline Tension SCF & 3.9819 & 1.8582 \\
0.1401 & 0.0820 & 0.6013 \\
0.2302 & 0.1472 & 1.0131 \\
0.3180 & 0.1993 & 1.3793 \\
0.4278 & 0.2509 & 1.7612 \\
0.5016 & 0.2931 & 1.9696 \\
\hline
\end{tabular}

Table 9 IPB model SCF

\begin{tabular}{ccc}
\hline \hline Interlink angle [deg] & $\mathrm{A}^{\prime}$ & $\mathrm{B}^{\prime}$ \\
\hline Tension SCF & 4.0336 & 2.3231 \\
0.1396 & 0.0345 & 0.2538 \\
0.2314 & 0.0810 & 0.4135 \\
0.3146 & 0.1219 & 0.5459 \\
0.4118 & 0.1832 & 0.6865 \\
0.5016 & 0.1881 & 0.8037 \\
\hline
\end{tabular}




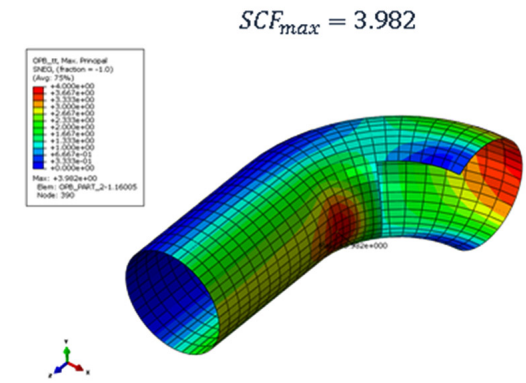

$S C F_{T T}$

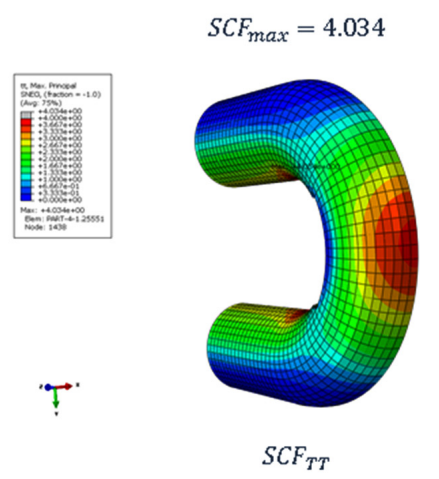

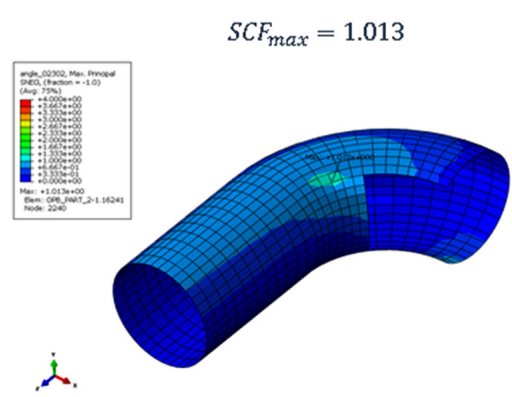

$S C F_{O P B}$ Interlink angle : $0.23^{\circ}$

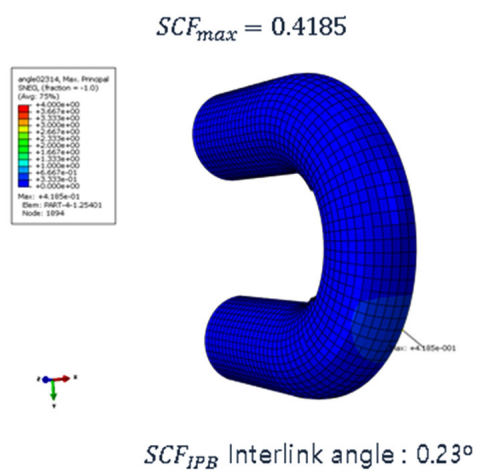

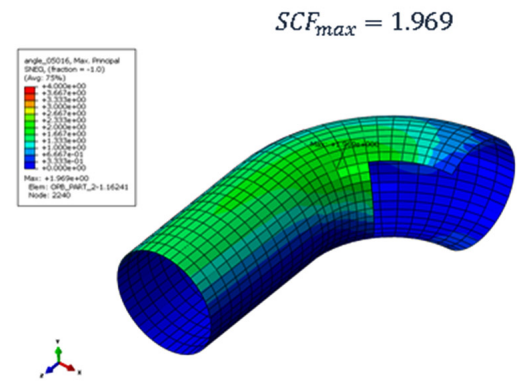

$S C F_{O P B}$ Interlink angle : $0.50^{\circ}$

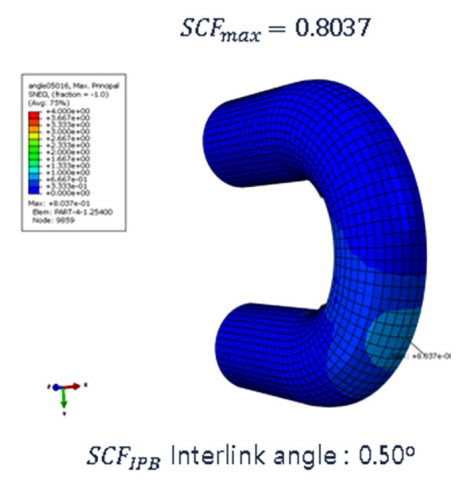

Fig. 21 Example of SCF under tension $1850 \mathrm{kN}$
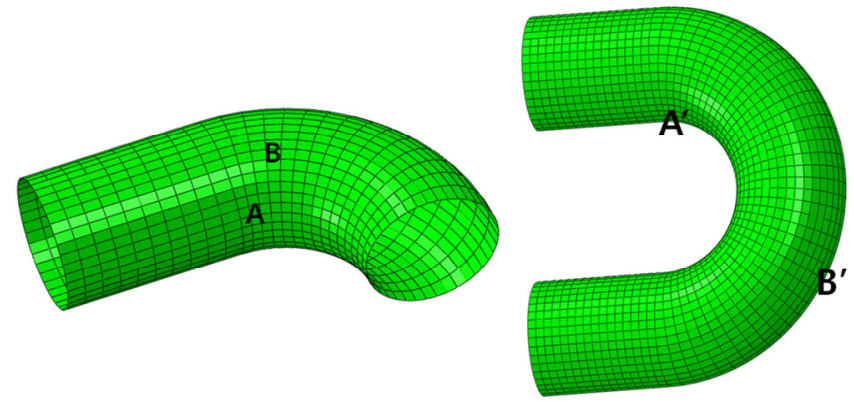

Fig. 22 Nodes on OPB/IPB chain model surface

링크 간 각도가 유사한 경우에 있어 면외 굽힘모드의 경우 가 면내 굽힘모드에 비해 큰 응력집중계수 값을 보여줌을 확 인할 수 있으며, 이는 계류라인의 피로설계에 있어 면외 굽힘 모드가 면내 굽힘모드에 비해 더 지배적인 현상임을 나타내는 결과이다.

\section{5. 결 론}

본 연구에서는 면 내외 굽힘을 고려한 계류라인 상부 체인의 피로해석을 위해 경계조건이 서로 다른 3 가지 모델의 비선형 수치해석을 통해 링크 간 강성에 영향을 주는 해석 인자들을 영향을 확인하고 응력집중계수를 도출 하였다. 상기의 연구를 토대로 다음과 같은 결론을 도출하였다.

(1) 유한요소해석을 통해 면 내외 굽힘모멘트 계산을 검증한 결과 해석 모델의 형상에 따라 결과 값의 차이가 남을 확인하 였다. 해석 결과의 차이는 다양한 인자로 유발되었을 것이나 경 계조건의 영향, 굽힘 모멘트의 산정식 및 체인링크의 탄성변형
등이 주요 원인이 되었을 것으로 판단된다.

(2) 대변형의 효과, 인장력의 크기, 마찰계수 및 굽힘 모멘트 계산 위치에 따른 링크 간 강성의 변화양상을 검토 하였으며, 상기 기술된 인자에 따른 링크 간 강성의 변화는 있었으나 그 효과는 그다지 크게 나타나지 않음을 확인하였다.

(3) 탄성 쿨롱마찰모델에 적용된 임계탄성 미끌림량이 링크 간 강성에 주는 영향은 상대적으로 크게 나타남을 확인하였다. 보다 정확한 해석을 위해서는 임계 탄성미끌림량의 크기에 대 한 결정이 중요한 인자이며, 이는 미끌림이 발생하는 체인의 표 면에 크게 영향을 받는 것으로 체계적인 실험을 통해 그 값을 결정하는 것이 타당한 것으로 판단된다.

(4) 유한요소해석을 통해 체인링크 간 접촉부를 제외한 체인 응력 집중부의 최대 주응력과 체인 중앙부 공칭 단면에 대한 공칭 인장응력의 비로써 정의되는 응력집중계수를 도출한 결과 체인의 굽힘에 의해 최대응력의 발생지점이 이동하는 것을 확 인할 수 있었다. 또한 응력집중계수 값에 있어 면외 굽힘모드의 경우 면내 굽힘모드에 비해 비교적 큰 값을 가짐을 확인하였고 이는 계류라인 피로설계에 있어 면외 굽힘모드가 더 지배적인 영향을 줄 것이라 판단된다.

\section{References}

Bureau Veritas, 2014. Fatigue of Top Chain of Mooring Lines Due to In-plane and Out-of-plane Bendings. Guidance Note NI 604 DT R00 E.

Choung, J., Han, S., 2016. A Novel Procedure for Mooring Chain Fatigue Prediction Based on Maximum Principal Stress Considering Out-of-plane and In-plane Bending Effect. 
Journal of the Society of Naval Architecture of Korea, 53(3), 237-248.

Hwang, O.J., 2012. Fatigue Assessment of Mooring Chain Link of Spread-moored FPSO in Deepwater Considering Bending Shenomenon. Ph.D., Dissertation, Korea Maritime and Ocean University.

Lim, Y., Kim, K., Choung, J., Kang, C., 2010. A Study on Out-of-Plane Bending Mechanism of Mooring Chains for Floating Offshore Plants. Journal of the Society of Naval Architects of Korea, 47(4), 580-588.

Melis, C., Jean, P., Vargas, P.M., 2005. Out-of-Plane Bending Testing of Chain Links. Proceedings of 24th International Conference on Offshore Mechanics and Arctic Engineering, Halkidiki, Greece.

Ramberg, W., Osgood, W., 1943. Description of Stress-Strain Curves by Three Parameters. National Advisory Committee for Aeronautics, Technical Note No. 902.

Rampi, L., Bignonnet, A., Le Cunff, C., Bourgin, F., Vargas, P., 2016a. Chain Out of Plane Bending(OPB) Fatigue Joint Industry Project(JIP) FEA Results and Multiaxiality Study Results. Proceedings of 35th International Conference on Offshore Mechanics and Arctic Engineering, Busan, Korea. Rampi, L., Gerthoffert, A., Francois, M., Bignonnet, A., Vargas, P., 2016b. Chain Out of Plane Bending(OPB) Fatigue Joint Industry Porject(JIP) Fatigue Test Program Results and Methodology. Proceedings of 35th International Conference on Offshore Mechanics and Arctic Engineering, Busan, Korea. Vargas, P.M, Jean, P., 2005. FEA of Out-of-Plane Fatigue Mechanism of Chain Links. Proceedings of 24th International Conference on Offshore Mechanics and Arctic Engineering, Halkidiki, Greece. 